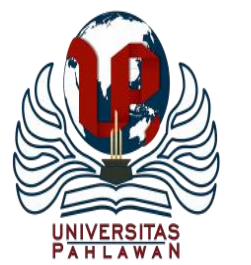

Edukatif : Jurnal Ilmu Pendidikan Volume 3 Nomor 5 Tahun 2021 Halm 2683 - 2695

EDUKATIF: JURNAL ILMU PENDIDIKAN

Research \& Learning in Education

https:/ledukatif.org/index.php/edukatif/index

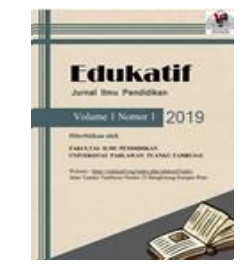

\title{
Kemampuan Pemahaman Konsep Matematis Siswa Sekolah Dasar melalui Pembelajaran Daring dengan Aplikasi Whatsapp
}

\author{
Nurul Fitri Shofiah ${ }^{1 凶}$, Jayanti Putri Purwaningrum $^{2}$, Fina Fakhriyah $^{3}$ \\ Universitas Muria Kudus, Indonesia ${ }^{1,2,3}$ \\ E-mail : shofi.fitri05@gmail.com ${ }^{1}$, jayanti.putri@umk.ac.id ${ }^{2}$, fina.fakhriyah@umk.ac.id ${ }^{3}$
}

\begin{abstract}
Abstrak
Pembelajaran matematika secara daring melalui aplikasi WhatsApp dapat mempengaruhi tingkat kemampuan pemahaman konsep matematis siswa. Hal ini dibuktikan dengan kenyataan yang ditemui di kelas V SDN 1 Sidomulyo, Blora. Tujuan penelitian ini untuk mendeskripsikan hasil belajar dan mengetahui kemampuan pemahaman konsep matematis siswa pada pembelajaran daring melalui aplikasi WhatsApp. Pembelajaran daring merupakan pembelajaran jarak jauh dengan memanfaatkan jaringan internet. Proses pembelajaran daring ini menggunakan aplikasi WhatsApp sebagai media komunikasi dalam pembelajaran. Jenis penelitian ini adalah deskriptif kualitatif. Penelitian ini dilaksanakan di kelas V SDN 1 Sidomulyo Kabupaten Blora. Teknik pemilihan subjek penelitian menggunakan teknik proporsional random sampling. Subjek penelitian berjumlah 9 siswa dengan kategori yaitu 4 siswa dengan hasil belajar tinggi, 2 siswa dengan hasil belajar sedang, dan 3 siswa dengan hasil belajar rendah. Instrumen penelitian ini menggunakan pedoman wawancara dan tes kemampuan pemahaman konsep matematis. Berdasarkan penelitian di lapangan dapat diketahui bahwa hasil kemampuan pemahaman konsep matematis siswa secara keseluruhan memiliki rata-rata 65,55 dengan rincian kategori tinggi didapatkan rata-rata 20,55\%, kategori sedang didapatkan rata-rata 43,07\%, dan kategori rendah didapatkan ratarata 36,38\%. Maka dari itu dapat disimpulkan bahwa hasil kemampuan pemahaman konsep matematis siswa tergolong dalam kategori cukup baik.
\end{abstract}

Kata Kunci: Kemampuan Pemahaman Konsep Matematis, Pembelajaran Daring, WhatsApp.

\begin{abstract}
Learning mathematics online with the WhatsApp application can affect the level of students' understanding of mathematical concepts. This is evidenced by the facts found in class V SDN 1 Sidomulyo, Blora. The purpose of the study was to describe learning outcomes and determine the ability to understand students' mathematical concepts in online learning through the WhatsApp application. This type of research is descriptive qualitative. The research was conducted in the fifth grade of SDN 1 Sidomulyo, Blora. The subject selection technique used a proportional random sampling technique. The research subjects were 9 students, including 4 students with high learning outcomes, 2 students with moderate learning outcomes, and 3 students with low learning outcomes. The research instrument was used to interview and test guidelines. Based on the results of the study, it can be seen that the ability to understand mathematical concepts of students as a whole has an average of 65.55 with details of the high category getting an average of 20.55\%, the medium category getting an average of $43.07 \%$, and the low category getting an average of $36.38 \%$. So it can be concluded that the results of students' mathematical concept understanding abilities are categorized as quite good.
\end{abstract}

Keywords: Ability to Understand Mathematical Concepts, Online Learning, WhatsApp

Copyright (c) 2021 Nurul Fitri Shofiah, Jayanti Putri Purwaningrum, Fina Fakhriyah

$\triangle$ Corresponding author

Email : shofi.fitri05@gmail.com

DOI : https://doi.org/10.31004/edukatif.v3i5.907

ISSN 2656-8063 (Media Cetak)

ISSN 2656-8071 (Media Online) 
2684 Kemampuan Pemahaman Konsep Matematis Siswa Sekolah Dasar melalui Pembelajaran Daring dengan Aplikasi Whatsapp - Nurul Fitri Shofiah, Jayanti Putri Purwaningrum, Fina Fakhriyah

DOI: https://doi.org/10.31004/edukatif.v3i5.907

\section{PENDAHULUAN}

Matematika merupakan ilmu yang berperan penting dalam kehidupan dan bersosialisasi di masyarakat. Salah satu tujuan pembelajaran matematika yang dikemukakan oleh Kemendikbud 2013 adalah membentuk kemampuan siswa dalam menyelesaikan suatu masalah secara sistematis. Siswa yang mampu menyelesaikan masalah secara sistematis berarti telah memiliki pemahaman yang bagus dan mengetahui ide-ide matematika yang masih terkait. Pemahaman dalam pembelajaran matematika sudah seharusnya ditanamkan oleh guru kepada siswanya. Tanpa pemahaman siswa tidak akan dapat mengaplikasikan proses, konsep dan langkah.

Pada pembelajaran matematika, pemahaman yang paling diutamakan adalah pemahaman konsep. Kemampuan pemahaman konsep matematika sangat penting karena disamping menjadi salah satu tujuan pembelajaran matematika, kemampuan pemahaman konsep juga dapat membantu siswa untuk tidak hanya sekedar menghafal rumus, tetapi dapat mengerti benar apa makna dalam pembelajaran matematika(Pitaloka dan Mulyono, 2013). Pemahaman konsep dalam pembelajaran matematika merupakan landasan penting dalam menyelesaikan permasalahan matematika maupun permasalahan sehari-hari. Hal ini sesuai dikemukakan oleh (Arnidha, 2017) bahwa pemahaman konsep matematis sangat diperlukan dalam pembelajaran matematika di sekolah dasar. Artinya, dalam pembelajaran matematika siswa harus memahami konsep dengan baik agar dapat menyelesaikan soal-soal dan mampu mengaplikasikan pembelajaran tersebut dalam kehidupan seharihari.

Adapun indikator kemampuan pemahaman konsep matematis menurut Permendikbud no 58 tahun 2014 adalah: a) Menyatakan ulang konsep yang telah dipelajari. b) Mengklasifikasikan objek-objek berdasarkan dipenuhi tidaknya persyaratan yang membentuk konsep tersebut. c) Mengidentifikasi sifat-sifat operasi atau konsep. d) Menerapkan konsep secara logis. e) Memberikan contoh atau contoh kontra (bukan contoh) dari konsep yang telah dipelajari. f) Menyajikan konsep dalam berbagai macam bentuk representasi matematis (tabel, grafik, diagram, gambar, sketsa, model matematika atau cara lainnya). (g) Mengaitkan berbagai konsep dalam matematika maupun luar matematika. (h) Mengembangkan syarat perlu dan atau syarat cukup suatu konsep (Arrahim dan Widayanti, 2018).

Kesulitan yang ada dalam mata pelajaran matematika menuntut kreativitas guru untuk mengembangkan pembelajarannya, baik dalam hal metode maupun media yang digunakan (Mustakim, 2020). Hal ini merupakan tantangan tersendiri untuk dunia pendidikan supaya pembelajaran dapat terus berjalan meskipun pandemi Covid-19 masih merebak. Salah satu jalan keluar untuk menangani masalah tersebut adalah pembelajaran dilakukan secara daring (Handarini dan Wulandari, 2020). Pembelajaran yang biasanya dilakukan secara tatap muka di ruang kelas, saat ini harus berubah menjadi pembelajaran daring (dalam jaringan) dan pembelajaran matematika yang bermakna tidak sepenuhnya terealisasi. Hal ini disebabkan karena adanya Covid Virus Disease (Covid-19) yang melanda hampir seluruh dunia khususnya Indonesia. Sehingga dengan adanya Covid-19 ini sektor pendidikan mengalami tantangan baru dan secara cepat harus membuat kebijakan yaitu dengan menerapkan pembelajaran daring (Patimah dan Maula, 2020). Pembelajaran daring adalah salah satu alternatif pembelajaran yang dapat berlangsung meskipun siswa tidak berada di ruang kelas. Siswa dapat melaksanakan pembelajaran dan berinteraksi dengan guru menggunakan beberapa aplikasi seperti Google Classroom, Video Conference, telepon atau Live Chat, Zoom maupun melalui WhatsApp group(Dewi, 2020).

Pembelajaran daring yang digunakan dalam penelitian ini adalah melalui bantuan aplikasi WhatsApp dan dipandu langsung oleh guru kelas. Pembelajaran matematika yang dilakukan secara daring melalui WhatsApp tidaklah mudah bagi guru dalam menyampaikan materi. Apalagi siswa yang diajar guru adalah siswa Sekolah Dasar yang pada umumnya masih membutuhkan bimbingan secara langsung oleh guru ketika belajar. Selama ini mata pelajaran matematika menjadi salah satu mata pelajaran yang dianggap sesuatu yang menakutkan bagi siswa. Dengan pembelajaran tatap muka saja banyak siswa yang mengalami kesulitan, 
2685 Kemampuan Pemahaman Konsep Matematis Siswa Sekolah Dasar melalui Pembelajaran Daring dengan Aplikasi Whatsapp - Nurul Fitri Shofiah, Jayanti Putri Purwaningrum, Fina Fakhriyah

DOI: https://doi.org/10.31004/edukatif.v3i5.907

apalagi jika dilaksanakan secara daring. Maka dari itu, untuk menghadapi permasalahan tersebut, guru dituntut untuk lebih variatif dan kreatif dalam proses pembelajaran matematika (Jehamun, 2020). Untuk menumbuhkan antusias, minat dan bakat siswa, perlu adanya metode, model serta strategi pembelajaran yang diterapkan agar siswa mudah memahami materi pembelajaran matematika dengan tidak menghafal materi dan rumus tetapi siswa diharapkan memahami konsepnya (Anggraeni, 2020).

Pada masa pandemi Covid-19, siswa belajar mandiri di rumah bersama orangtua sesuai dengan materi yang dikirimkan guru melalui WhatsApp. Berdasarkan evaluasi analisis mendalam terkait kemampuan pemahaman konsep matematis yang dimiliki siswa selama melaksanakan pembelajaran daring, proses pembelajaran menjadi terganggu dan dibiarkan siswa akan kesulitan dalam pengaplikasian dengan kehidupan sehari-hari. Selain itu pembelajaran matematika merupakan dasar bagi penerapan konsep matematika ke jenjang berikutnya. Maka dari itu, perlu adanya suatu evaluasi pembelajaran yang dilakukan guru dalam menerapkan pembelajaran matematika secara daring.

Beberapa penelitian terkait analisis kemampuan pemahaman matematis telah banyak dilakukan. Penelitian yang dilakukan(Yulianah et al., 2020) berjudul "Analisis Kemampuan Pemahaman Konsep Matematika Siswa Berbantuan Media Schoology". Hasil penelitian menunjukkan bahwa kesulitan pembelajaran matematika yang dihadapi siswa dikarenakan metode yang digunakan dalam pembelajaran cenderung monoton. Pembelajaran hanya difokuskan pada pendidik dan tidak variatifnya pembelajaran yang dilakukan mempengaruhi siswa dalam memahami konsep dari materi yang diberikan. Sehingga pembelajaran yang dilakukan di kelas menimbulkan kejenuhan tersendiri bagi peserta didik. Selanjutnya, penelitian yang dilakukan (Rahmawati dan Maula, 2020) yang berjudul "Analisis Pemahaman Konsep Matematis Siswa Berdasarkan Teori APOS melalui Soal Open Ended Berbasis Daring di kelas Tinggi Sekolah Dasar". Hasil penelitian menunjukkan bahwa pemahaman konsep matematis siswa IV SD Negeri Lembursitu Kota Sukabumi dalam materi luas dan keliling bangun datar perlu adanya suatu teori pengkajian dalam proses pembelajaran daring. Kurangnya pemahaman konsep matematis siswa dalam menyelesaikan soal open ended berbasis daring menjadikan guru untuk melakukan evaluasi pengkajian teori Luas dan Keliling Bangun Datar melalui teori APOS. Teori APOS merupakan penyelesaian pemahaman konsep matematika melalui beberapa kegiatan tahapan diantaranya: Aksi (Action), Proses (Process), Objek (Object), dan Skema (Schema). Sehingga dengan hal ini siswa mampu menyelesaikan soal pemahaman konsep matematika daring yang berbasis open ended dengan runtut dan baik.

Adapun keterbaruan dalam penelitian ini adalah menganalisis kemampuan pemahaman konsep matematis siswa kelas V SD pada materi volume balok dan volume kubus selama pembelajaran daring dengan menggunakan aplikasi WhatsApp. Melalui kajian mendalam akan diperoleh hasil belajar dan gambaran kemampuan pemahaman konsep matematika siswa. Selanjutnya, guru dapat merancang pembelajaran yang tepat untuk meningkatkan kemampuan matematika siswa.

Berdasarkan analisis pembahasan sebelumnya, terdapat permasalahan pemahaman konsep matematis siswa kelas V SDN 1 Sidomulyo, Blora pada materi volume balok dan volume kubus ketika pembelajaran daring melalui aplikasi WhatsApp. Sehingga peneliti tertarik untuk meneliti dan memperoleh gambaran kemampuan pemahaman matematis siswa selama pembelajaran daring berlangsung.

\section{METODE PENELITIAN}

Penelitian ini menggunakan metodologi kualitatif deskriptif. Penelitian ini menggambarkan analisis kemampuan pemahaman konsep matematis siswa kelas V SDN 1 Sidomulyo Blora selama pembelajaran daring dengan aplikasi WhatsApp yang berpedoman pada penskoran dan indikator kemampuan pemahaman konsep matematis. Penelitian ini dilakukan pada tanggal 19 April 2021 sampai dengan 27 Mei 2021. Subjek penelitian ini adalah 9 siswa dari 20 siswa di kelas V SDN 1 Sidomulyo yang diambil dengan teknik 
2686 Kemampuan Pemahaman Konsep Matematis Siswa Sekolah Dasar melalui Pembelajaran Daring dengan Aplikasi Whatsapp - Nurul Fitri Shofiah, Jayanti Putri Purwaningrum, Fina Fakhriyah

DOI: https://doi.org/10.31004/edukatif.v3i5.907

proporsional random sampling. Subjek penelitian ini terdiri dari 3 kriteria yaitu, 4 siswa dengan hasil belajar tinggi, 2 siswa dengan hasil belajar sedang dan 3 siswa dengan hasil belajar rendah. Adapun kriteria pengambilan subjek penelitian dilakukan secara proporsional random sampling berdasarkan nilai PAS (Penilaian Akhir Semester) mata pelajaran matematika.

Teknik pengambilan data ini menggunakan delapan butir soal uraian pemahaman konsep matematis siswa. Indikator kemampuan pemahaman konsep matematis menurut Permendikbud no 58 tahun 2014 adalah: a) Menyatakan ulang konsep yang telah dipelajari. b) Mengklasifikasikan objek-objek berdasarkan dipenuhi tidaknya persyaratan yang membentuk konsep tersebut. c) Mengidentifikasi sifat-sifat operasi atau konsep. d) Menerapkan konsep secara logis. e) Memberikan contoh atau contoh kontra (bukan contoh) dan konsep yang telah dipelajari. f) Menyajikan konsep dalam berbagai macam bentuk representasi matematis. (g) Mengaitkan berbagai konsep dalam matematika maupun luar matematika. (h) Mengembangkan syarat perlu dan atau syarat cukup suatu konsep. Teknik analisis data dilakukan dengan tiga tahap, yaitu: (1) mereduksi data, dalam hal ini peneliti menganalisis data hasil tes; (2) menyajikan data, dalam hal ini peneliti menyajikan data dalam bentuk uraian singkat, rubrik, dan gambar; dan (3) menarik kesimpulan. Prosedur dalam penelitian ini terdiri dari tiga tahap, yaitu: (1) tahap persiapan; (2) tahap pelaksanaan; dan (3) tahap akhir. Langkah-langkah pada tahap persiapan yang dilakukan, yaitu: (1) melakukan pra penelitian pada siswa kelas V SD; (2) menyiapkan soal penelitian untuk tes soal kemampuan pemahaman konsep matematis; dan (3) menyusun pedoman wawancara. Pada tahap pelaksanaan, diantaranya: (1) memberikan tes kepada siswa kelas V SD; (2) menganalisis jawaban subjek penelitian; dan (3) mewawancarai siswa dari apa yang dikerjakan. Pada tahap akhir adalah peneliti menganalisis data penskoran dengan sembilan subjek siswa terhadap kemampuan pemahaman konsep matematis dengan menggunakan rubrik penilaian seperti pada Tabel 1.

Tabel 1.Kriteria penilaian kemampuan pemahaman konsep matematis

\begin{tabular}{cc}
\hline Indikator & Skor maksimal \\
\hline 1 & 5 \\
\hline 2 & 5 \\
\hline 3 & 5 \\
\hline 4 & 5 \\
\hline 5 & 5 \\
\hline 6 & 5 \\
\hline 7 & 5 \\
\hline 8 & 5 \\
\hline Jumlah Skor & $\mathbf{4 0}$ \\
\hline
\end{tabular}

Analisis kemampuan pemahaman konsep pada setiap subjek dilakukan berdasarkan indikator kemampuan pemahaman (Pollatsek dalam Sumarmo, 2010). Analisis kemampuan pemahaman konsep pada setiap subjek dilakukan untuk menganalisis kemampuan pemahaman konsep matematis siswa pada tiap indikator. Dalam hal ini, peneliti membuat pedoman untuk mengklasifikasikan kemampuan siswa pada tiap indikator kemampuan pemahaman konsep matematis seperti pada Tabel 2.

Tabel 2. Pedoman Pengklasifikasian Kemampuan Siswa pada Setiap Indikator KPKM

\begin{tabular}{cc}
\hline Klasifikasi & Banyak Soal yang dipenuhi Tiap Indikator \\
\hline Baik & $\geq 6$ \\
\hline Cukup Baik & 5 \\
\hline Kurang Baik & $\leq 4$ \\
\hline
\end{tabular}


2687 Kemampuan Pemahaman Konsep Matematis Siswa Sekolah Dasar melalui Pembelajaran Daring dengan Aplikasi Whatsapp - Nurul Fitri Shofiah, Jayanti Putri Purwaningrum, Fina Fakhriyah

DOI: https://doi.org/10.31004/edukatif.v3i5.907

Selanjutnya, untuk menghitung hasil belajar tes kemampuan pemahaman konsep matematis (KPKM) menggunakan rumus berikut:

$$
\text { Hasil Tes KPKM }=\frac{\text { SkoryangdiperolehSiswa }}{\text { SkorMaksimal }} \times 100
$$

Hasil tes kemampuan pemahaman konsep matematis kemudian dikelompokkan kedalam 5 kategori, yaitu sangat baik, baik, cukup, kurang, dan sangat kurang. Berikut adalah interpretasi nilai kemampuan pemahaman konsep matematis siswa yang mengikuti tes dengan berbagai macam kategori.

Tabel 3. Interpretasi Nilai Kemampuan Pemahaman Konsep Matematis Siswa

\begin{tabular}{cc}
\hline Nilai & Kriteria \\
\hline $85,00-100$ & Sangat Baik \\
\hline $70,00-84,99$ & Baik \\
\hline $55,00-69,99$ & Cukup \\
\hline $40,00-54,99$ & Kurang \\
\hline $0-39,99$ & Sangat Kurang \\
\hline Kartika, 2018) &
\end{tabular}

\section{HASIL DAN PEMBAHASAN PENELITIAN}

Berdasarkan tes yang dilakukan pada kelas V SDN 1 Sidomulyo Blora terdapat 20 siswa tetapi dalam tes kemampuan pemahaman konsep matematis dengan pembelajaran daring ini hanya 9 orang siswa yang mengerjakan karena berdasarkan penentuan ukuran subjek dengan teknik proporsionalrandom sampling yang diambil dari nilai Penilaian Akhir Semester (PAS) pada mata pelajaran matematika di kelas V tahun 2020/2021. Pada penelitian ini memfokuskan kepada siswa yang mengikuti tes kemampuan pemahaman konsep matematis. Berikut adalah nilai hasil tes kemampuan pemahaman konsep matematis siswa yang mengikuti tes dengan berbagai macam kriteria.

Tabel 4. Nilai Hasil Tes Kemampuan Pemahaman Konsep Matematis Siswa

\begin{tabular}{ccc}
\hline Nilai & Kriteria & Banyak Siswa \\
\hline $85,00-100$ & Sangat Baik & 1 \\
\hline $70,00-84,99$ & Baik & 2 \\
\hline $55,00-69,99$ & Cukup & 5 \\
\hline $40,00-54,99$ & Kurang & 1 \\
\hline $0-39,99$ & Sangat Kurang & 0 \\
\hline
\end{tabular}

Berdasarkan Tabel 4 di atas, hasil tes kemampuan pemahaman konsep matematis siswa menunjukkan bahwa 1 orang siswa dengan kriteria sangat baik, 2 orang siswa dengan kriteria baik, 5 orang siswa dengan kriteria cukup, 1 orang siswa dengan kriteria kurang, dan 0 orang siswa dengan kriteria sangat kurang. Jadi, jika dilihat dari tabel di atas dapat disimpulkan bahwa rata-rata siswa kelas V SDN 1 Sidomulyo mampu mengerjakan tes kemampuan pemahaman konsep matematis yang diberikan, karena $56 \%$ dari siswa yang mengerjakan soal tes kemampuan pemahaman konsep matematis tersebut memiliki nilai dengan kategori cukup, yaitu rentang skor 55,00 sampai 69,99. Adapun analisis kemampuan pemahaman konsep matematis tiap indikator soal adalah sebagai berikut. 
2688 Kemampuan Pemahaman Konsep Matematis Siswa Sekolah Dasar melalui Pembelajaran Daring dengan Aplikasi Whatsapp - Nurul Fitri Shofiah, Jayanti Putri Purwaningrum, Fina Fakhriyah

DOI: https://doi.org/10.31004/edukatif.v3i5.907

\section{Soal pertama dengan indikator menyatakan ulang konsep yang telah dipelajari.}

Berdasarkan soal nomor 1 dengan indikator soal menentukan ukuran panjang, lebar dan tinggi balok pada kubus satuan serta menentukan besar volume balok, dari 9 siswa didapat ada 4 siswa menjawab benar dan mendapat skor 5, 3 siswa menjawab kurang tepat dan mendapat skor 3, dan 2 siswa menjawab tidak tepat dan mendapat skor 1. Adapun siswa yang menjawab benar adalah ZDU, VO, AAN, dan AFR dengan alternatif jawaban sebagai berikut:

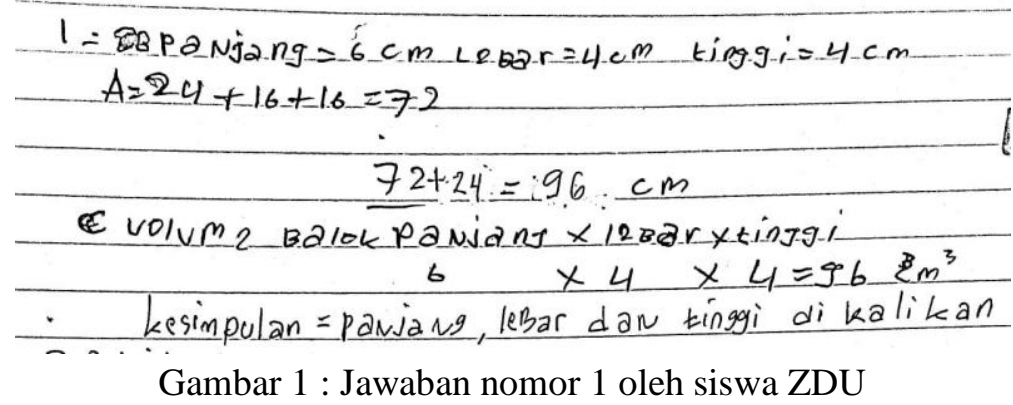

Lain halnya dengan tiga siswa yang menjawab kurang tepat, yaitu MIM, YK, dan MABI dengan menjawab soal sebagai berikut.

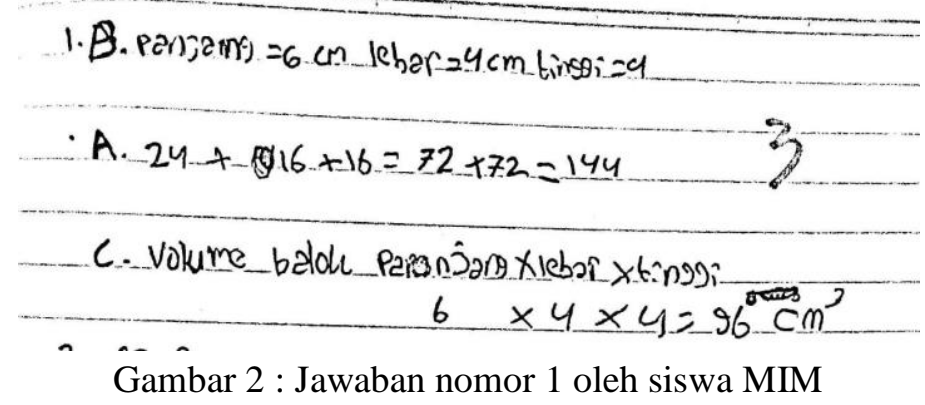

Pada jawaban soal nomor 1, MIM memiliki kesalahan dalam menghitung keseluruhan jumlah panjang, lebar dan tinggi. Soal yang ditanyakan berhubungan dengan konsep volume balok dari satuan kubus, namun MIM tidak dapat menentukan jumlah kubus satuan pada balok. MIM juga tidak memberikan kesimpulan konsep penemuan volume balok. Sanjaya (Murtianto et al., 2019) mengemukakan bahwa seseorang dikatakan memahami konsep apabila mampu menerangkan konsep secara verbal mengenai apa yang sudah dicapainya. Akan tetapi berdasarkan wawancara yang dilakukan dengan MIM mengenai konsep penemuan rumus volume balok, MIM tidak bisa menjelaskannya dengan tepat, MIM hanya menjelaskan rumus volume balok berdasarkan hafalannya saja. Hal tersebut yang menyebabkan MIM diberi skor 3, sesuai dengan pedoman penskoran yang berarti MIM menjawab dengan kriteria kurang tepat dalam menentukan panjang, lebar, tinggi dan volume balok.

Secara garis besar, dapat disimpulkan bahwa kemampuan pemahaman konsep matematis siswa dengan indikator menyatakan ulang konsep dari 9 siswa sangat bervariasi yaitu ada yang kemampuannya tinggi dan ada pula yang kemampuannya rendah. Namun dari keseluruhan rata-rata, siswa memiliki kemampuan menyatakan ulang konsep tergolong dalam kategori cukup baik.

\section{Soal kedua dengan indikator mengklasifikasikan objek-objek berdasarkan dipenuhi tidaknya persyaratan yang membentuk konsep.}

Berdasarkan soal nomor 2 dengan indikator soal mengklasifikasikan ukuran volume antara dua balok. Dari 9 siswa sebagian besar menjawab benar namun kurang lengkap. Ada pula siswa yang mampu menjawab 
2689 Kemampuan Pemahaman Konsep Matematis Siswa Sekolah Dasar melalui Pembelajaran Daring dengan Aplikasi Whatsapp - Nurul Fitri Shofiah, Jayanti Putri Purwaningrum, Fina Fakhriyah

DOI: https://doi.org/10.31004/edukatif.v3i5.907

dengan tepat dan jelas. Adapun siswa yang menjawab dengan tepat dan jelas diberikan skor 5 berjumlah 1 siswa, siswa tersebut adalah YK. Adapun jawaban yang dikemukakan adalah sebagai berikut:

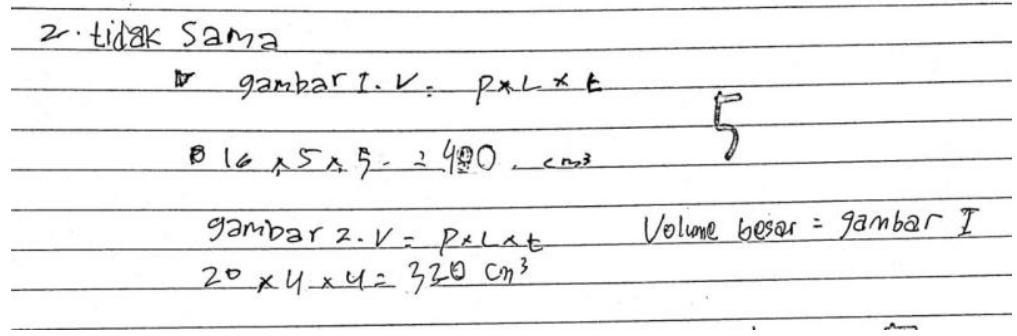

Gambar 3 : Jawaban nomor 2 oleh siswa YK

Lain halnya dengan 8 siswa yang mampu menjawab namun kurang lengkap, yaitu AFR, B, VO, AAN, MABI, MIM, ZDU, dan FDP menjawab soal sebagai berikut:

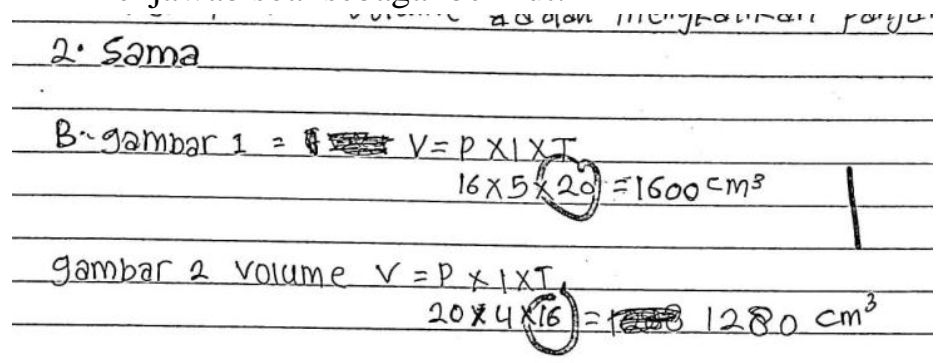

Gambar 4 : Jawaban nomor 2 oleh siswa AAN

Secara garis besar dapat disimpulkan bahwa kemampuan pemahaman konsep matematis siswa dengan indikator mengklasifikasikan objek-objek berdasarkan dipenuhi tidaknya persyaratan yang membentuk konsep dari 9 siswa sangat bervariasi yaitu ada yang kemampuannya tinggi dan ada pula yang kemampuannya rendah. Namun, dari keseluruhan sebagian besar siswa memiliki kemampuan mengklasifikasikan objek-objek berdasarkan dipenuhi tidaknya persyaratan yang membentuk konsep tergolong dalam kategori kurang baik (rendah).

\section{Soal ketiga dengan indikator mengidentifikasi sifat-sifat operasi atau konsep.}

Berdasarkan soal nomor 3 dengan indikator soal menyebutkan sifat-sifat kubus sesuai gambar, dari 9 siswa yang ada, semuanya menjawab dengan jelas dan tepat sehingga diberikan skor 5 . Adapun jawaban dari soal tersebut adalah sebagai berikut:

3). A. Memiliki \& titik sudut
1. Memiliki 12 cusuk
C. Memiliki 6 sisi

Gambar 5 : Jawaban nomor 3 oleh siswa AFR

Berdasarkan Gambar 5 di atas, AFR menjawab soal nomor 3 dengan jelas dan tepat begitupun dengan 8 siswa lainnya. Dapat disimpulkan bahwa kemampuan pemahaman konsep matematis siswa pada indikator mengidentifikasi sifat-sifat operasi atau konsep tergolong dalam kategori baik (tinggi). Sejalan dengan pernyataan (Arnidha, 2017)bahwa siswa harus mampu mengidentifikasi sifat-sifat suatu konsep dan mengenal syarat yang menentukan konsep ke dalam soal yang ditanyakan oleh peneliti. Hal ini karena dasar kemampuan matematis siswa berasal dari identifikasi sifat-sifat dan paham mengenai syarat dari materi yang dipelajari.

\section{Soal keempat dengan indikator menerapkan konsep secara logis}


2690 Kemampuan Pemahaman Konsep Matematis Siswa Sekolah Dasar melalui Pembelajaran Daring dengan Aplikasi Whatsapp - Nurul Fitri Shofiah, Jayanti Putri Purwaningrum, Fina Fakhriyah

DOI: https://doi.org/10.31004/edukatif.v3i5.907

Berdasarkan soal nomor 4 dengan indikator soal menerapkan hubungan antara sebuah konsep volume bangun ruang balok dengan prosedur yang tepat. Dari 9 siswa didapat ada 7 siswa menjawab benar dan mendapat skor 5, 2 siswa menjawab kurang tepat dan mendapat skor 3. Adapun siswa yang menjawab benar adalah AFR, B, VO, MABI, MIM, ZDU, dan FDP dengan alternatif jawaban sebagai berikut:

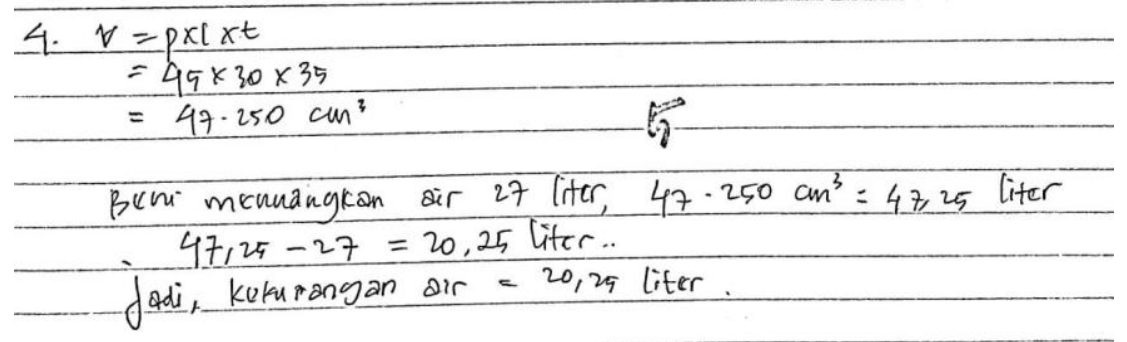

Gambar 6 : Jawaban nomor 4 oleh siswa VO

Berbeda dengan VO, kasus yang terjadi pada AAN dan YK kurang tepat dalam menentukan nilai kekurangan air pada akuarium yang ditanyakan. Konsep yang dipakai siswa salah dan siswa terlihat kurang memahami apa yang ditanyakan dalam soal. Sehingga skor yang didapatkan siswa adalah 3. Adapun salah satu jawaban yang dikemukakan adalah sebagai berikut:

$\begin{array}{r}\frac{4 \cdot V \cdot \text { balok } P X L X T}{45 \times 30 \times 35=47.250^{\mathrm{cm}^{3}}} \\ \hline 47.250-27=42.223 \mathrm{~cm}^{3}\end{array}$

Gambar 7 : Jawaban nomor 4 oleh siswa AAN

Secara garis besar dapat disimpulkan bahwa pengujian kemampuan pemahaman konsep matematis pada 9 siswa untuk indikator menerapkan konsep secara logis tergolong dalam kategori baik (tinggi).

\section{Soal kelima dengan indikator memberikan contoh atau contoh kontra (bukan contoh) dari konsep yang telah dipelajari.}

Berdasarkan soal nomor 5 yang indikator soalnya membahas tentang menentukan contoh dan bukan contoh dari konsep bangun ruang balok didapatkan data dari 9 siswa yang ada, sebanyak 8 siswa mampu memberikan jawaban dengan jelas dan tepat sehingga diberikan skor 5. Siswa tersebut diantaranya AFR, VO, AAN, MABI, YK, MIM, ZDU, dan FDP. Adapun salah satu jawaban yang dikemukakan adalah sebagai berikut:

5- bagian 2. Karena sisi-sisinya tidak sama besar dan ukuran panjang,
lebar dan tingginya juga berbeda.

Gambar 8 : Jawaban nomor 5 oleh siswa VO

Berbeda dengan jawaban di atas, siswa B ternyata tidak membaca perintah soal dengan seksama. Kesulitan yang dialami siswa B berasal dari kurangnya pemahaman dalam soal yang diberikan tetapi siswa tidak mau bertanya. Siswa B hanya menentukan bangun mana yang termasuk bangun ruang balok tanpa memberikan alasan apapun. Sehingga siswa B diberikan skor 1. Adapun jawaban yang dikemukakan siswa B adalah sebagai berikut:

$S$ bogian oua


2691 Kemampuan Pemahaman Konsep Matematis Siswa Sekolah Dasar melalui Pembelajaran Daring dengan Aplikasi Whatsapp - Nurul Fitri Shofiah, Jayanti Putri Purwaningrum, Fina Fakhriyah

DOI: https://doi.org/10.31004/edukatif.v3i5.907

Gambar 9 : Jawaban nomor 5 oleh siswa B

Secara garis besar dapat disimpulkan bahwa pengujian kemampuan pemahaman konsep matematis pada indikator memberikan contoh atau contoh kontra (bukan contoh) dari konsep yang telah dipelajari oleh siswa kelas V SDN 1 Sidomulyo tergolong dalam kategori baik (tinggi).

\section{Soal keenam dengan indikator menyajikan konsep dalam berbagai macam bentuk representasi matematis.}

Berdasarkan soal nomor 6 dengan indikator soalnya yaitu siswa menyajikan konsep volume kubus, dari 9 siswa yang ada terdapat 8 siswa yang mampu menyelesaikan soal dengan jelas dan tepat. Sehingga siswa diberikan skor 5. Adapun salah satu jawaban siswa dari soal tersebut adalah sebagai berikut:

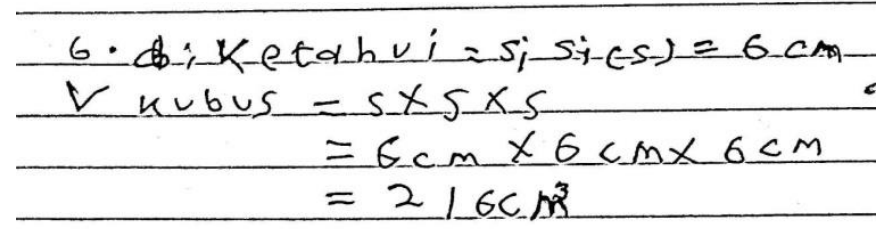

Gambar 10 : Jawaban nomor 6 oleh siswa MABI

Berbeda dengan jawaban di atas, siswa ZDU tidak dapat menyelesaikan soal nomor 6 karena berdasarkan wawancara yang telah dilakukan, siswa ZDU tidak paham dengan maksud soal yang diberikan. Padahal, cara terbaik untuk membantu siswa dalam memahami matematika adalah adalah dengan cara mendorong mereka untuk membuat suatu representasi (McCoy dkk.(Hutagaol, 2013)). Sehingga dapat disimpulkan bahwa secara garis besar pengujian kemampuan pemahaman konsep pada indikator menyajikan konsep dalam berbagai macam bentuk representasi matematis tergolong dalam kategori baik (tinggi).

\section{Soal ketujuh dengan indikator mengaitkan berbagai konsep dalam matematika maupun luar matematika.}

Berdasarkan soal nomor 7 dengan indikator soalnya adalah menyelesaikan masalah volume bangun ruang balok dalam kehidupan sehari-hari. Soal nomor 7 ini berhubungan dengan konsep yang sering ditemui siswa dalam kehidupan sehari-hari. Akan tetapi, hasil dari 9 siswa ini sangat bervariasi dan kebanyakan siswa belum mampu untuk mengerjakan suatu permasalahan volume balok dalam kehidupan sehari-hari. Skor yang diperoleh siswa paling tinggi adalah 5, yang berarti siswa sudah mampu mengerjakan soalnya dengan benar dan jelas. Siswa yang mendapatkan skor 5 ini hanya 3 siswa saja yaitu AFR, VO, dan YK. Adapun salah satu jawaban yang dikemukakan adalah sebagai berikut:

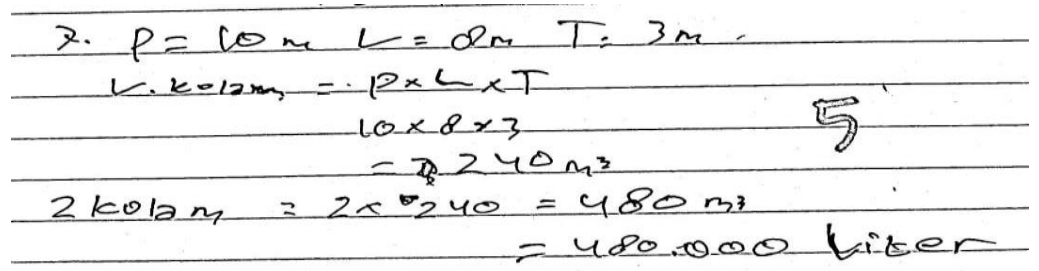

Gambar 11 :Jawaban nomor 7 oleh siswa YK

Berbeda dengan siswa AFR, VO, dan YK, sebanyak lima siswa mengaku tidak bisa menyelesaikan soal nomor 7. Lima siswa tersebut diantaranya: B, AAN, MABI, MIM dan FDP. Berdasarkan wawancara yang telah dilakukan dengan lima siswa tersebut, siswa menyatakan tidak mampu menyelesaikan soal yang diberikan karena siswa tidak menguasai permasalahan tersebut. Sehingga siswa diberikan skor 0. 
2692 Kemampuan Pemahaman Konsep Matematis Siswa Sekolah Dasar melalui Pembelajaran Daring dengan Aplikasi Whatsapp - Nurul Fitri Shofiah, Jayanti Putri Purwaningrum, Fina Fakhriyah

DOI: https://doi.org/10.31004/edukatif.v3i5.907

Selanjutnya, terdapat satu siswa yang berusaha menjawab soal nomor 7, akan tetapi jawabannya belum tepat, yaitu ZDU. Dalam mengerjakan soal nomor 7, ZDU kurang tepat dalam menentukan volume 2 kolam renang yang berbentuk balok. Siswa ZDU tidak teliti dalam memahami apa yang ditanyakan dalam soal. Maka dari itu, skor yang didapatkan siswa ZDU adalah 3. Adapan jawaban siswa ZDU adalah sebagai berikut:

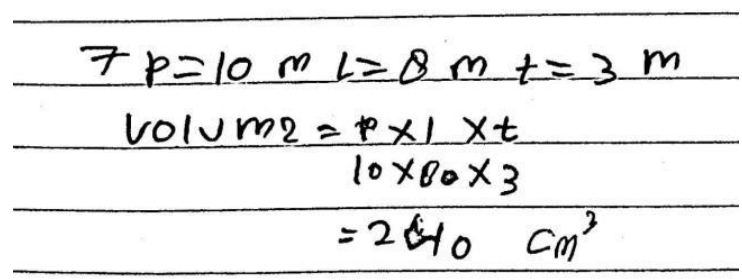

Gambar 12 : Jawaban soal nomor 7 oleh siswa ZDU

Hal ini dapat disimpulkan bahwa kemampuan pemahaman konsep matematis siswa dalam indikator mengaitkan berbagai konsep dalam matematika maupun luar matematika secara umum belum mampu menguasai dengan baik. Maka perlu adanya latihan secara sering supaya dapat dengan mudah menyelesaikan permasalahan matematika dalam kehidupan sehari-hari.

\section{Soal kedelapan dengan indikator mengembangkan syarat perlu dan atau syarat cukup suatu konsep.}

Berdasarkan soal nomor 8 dengan indikator soalnya adalah menentukan ukuran lebar pada bangun balok yang telah ditetapkan ukuran panjang, lebar dan volumenya. Dalam hal ini, siswa diminta untuk dapat mengembangkan syarat perlu dan syarat cukup dari konsep yang telah ditetapkan. Dari 9 siswa yang diuji, terdapat 5 siswa yang mampu menyelesaikan soal dengan benar dan jelas, 4 siswa lainnya tidak mampu menyelesaikannya. Sehingga siswa yang mampu menyelesaikan soal dengan benar dan jelas diberi skor 5 . Sedangkan, siswa yang tidak mampu menyelesaikan soal diberi skor 0. Adapun siswa yang menjawab benar dan jelas yaitu AFR, B, AAN, MABI, dan MIM. Salah satu jawaban yang dikemukakan adalah sebagai berikut:

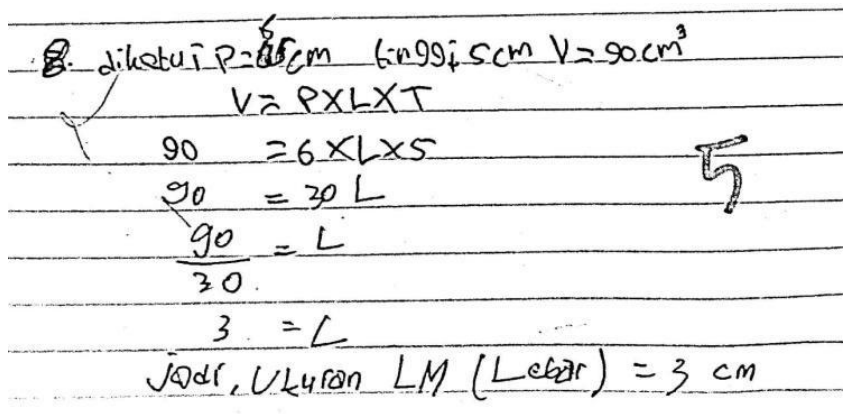

Gambar 13: Jawaban nomor 8 oleh siswa MIM

Adapun siswa yang tidak mampu menyelesaikan soal nomor 8 yaitu VO, YK, ZDU, dan FDP. Berdasarkan wawancara yang dilakukan dengan siswa VO dan YK menyatakan bahwa VO dan YK kekurangan waktu dalam menyelesaikan soal, sehingga soal tidak dapat dikerjakan dengan baik. Sedangkan siswa ZDU dan FDP dalam wawancara menyatakan bahwa ZDU dan FDP tidak mampu menyelesaikan dan merasa kesulitan terhadap soal yang diberikan. Hal ini dapat disimpulkan bahwa kemampuan pemahaman konsep matematis siswa dalam indikator mengembangkan syarat perlu dan atau syarat cukup suatu konsep tergolong pada kategori kurang baik (rendah). Maka perlu adanya latihan secara sering agar dapat menyelesaikan permasalahan matematika dalam kehidupan sehari-hari dengan mudah. 


\section{Kemampuan Pemahaman Konsep Matematis Siswa Sekolah Dasar melalui Pembelajaran Daring dengan Aplikasi Whatsapp - Nurul Fitri Shofiah, Jayanti Putri Purwaningrum, Fina Fakhriyah \\ DOI: https://doi.org/10.31004/edukatif.v3i5.907}

Berdasarkan delapan indikator dalam pembahasan yang sudah dijelaskan, maka dapat ditarik kesimpulan bahwa kemampuan pemahaman konsep matematis siswa kelas V SDN 1 Sidomulyo dari 9 siswa yang paling tinggi adalah menguasai kemampuan dalam mengidentifikasi, menerapkan, memberikan contoh, menyajikan dan mengembangkan konsep pada operasi tertentu. Hal ini sesuai yang dikatakan oleh (Yanti, 2020) bahwa kemampuan pemahaman konsep siswa dapat dikatakan paling tinggi karena sebagian besar siswa menjawab dengan benar dan letak kesalahannya sangat sedikit. Sedangkan, kemampuan pemahaman konsep paling rendah terletak pada bagian indikator menyatakan ulang konsep yang telah dipelajari, mengklasifikasikan objek-objek berdasarkan dipenuhi tidaknya persyaratan yang membentuk konsep dan mengaitkan berbagai konsep dalam matematika maupun luar matematika. Hal ini sejalan dengan penelitian yang dilakukan oleh (Kartika, 2018) bahwa rendahnya kemampuan pemahaman konsep dikarenakan peserta didik kurang mampu menjelaskan atau menuangkan kembali konsep yang mereka dapatkan dan menyajikan konsep dalam bentuk representasi matematis sehingga peserta didik kurang akan kemampuan pemahaman konsep.

Kesulitan dalam penyelesaian soal tentunya dialami oleh siswa. Kesulitan tersebut dikarekan siswa kurang dapat memahami soal yang diujikan. Siswa mengaku kebingungan dalam menerjemahkan soal uraian dalam bentuk cerita. Hal ini dikarenakan siswa tidak menerima konsep secara langsung (daring) dalam pembahasan soal cerita dengan guru. Selain itu, siswa juga enggan bertanya pada guru dan hanya memilih untuk pasrah dalam memahami soal yang diberikan. Hal ini sejalan dengan hasil penelitian (Utami \& Cahyono, 2020) bahwa siswa tidak menerima konsep secara langsung antara siswa dan guru sehingga menyebabkan siswa hanya bisa pasrah karena tidak paham terhadap soal yang diberikan melalui daring.

Berdasarkan uraian hasil penelitian diatas, peneliti mengalami beberapa keterbatasan dalam menyelesaikan penelitian, diantaranya yaitu: pertama, keterbatasan waktu. Penelitian ini dilaksanakan di rumah siswa, sehingga waktu penelitian harus menyesuaikan jadwal kegiatan belajar daring siswa. Hal ini membuat peneliti hanya melaksanakan penelitian sesuai dengan fokus penelitian. Kedua, keterbatasan tempat. Penelitian ini hanya dilaksanakan di rumah subjek penelitian sehingga memungkinkan adanya perbedaan hasil apabila penelitian ini dilaksanakan dengan subjek yang berbeda. Ketiga, Keterbatasan kemampuan. Penelitian ini tidak terlepas dari ilmu teori yang dimiliki peneliti, peneliti sudah berusaha semaksimal mungkin untuk menyusun hasil penelitian sesuai prosedur dan arahan. Keempat, penelitian ini hanya menganalisis pada aspek kemampuan pemahaman konsep matematis siswa pada pembelajaran daring dengan aplikasi WhatsApp, sedangkan aspek lain yang memungkinkan mempengaruhi hasil tidak diteliti.

\section{KESIMPULAN}

Berdasarkan hasil penelitian yang dilakukan di kelas V SDN 1 Sidomulyo, dapat ditarik kesimpulan bahwa kemampuan pemahaman konsep matematis siswa dengan kategori hasil belajar tinggi mempunyai kemampuan pemahaman konsep yang baik walaupun pembelajaran dilakukan secara daring melalui WhatsApp. Ada pula siswa dengan kategori hasil belajar tinggi mempunyai kemampuan pemahaman konsep cukup baik. Untuk siswa dengan kategori hasil belajar sedang juga mempunyai kemampuan pemahaman konsep matematis yang cukup baik. Sedangkan, siswa dengan kategori hasil belajar rendah tetap mempunyai kemampuan pemahaman konsep matematis yang kurang baik. Dari kedelapan indikator kemampuan pemahaman konsep matematis siswa yang paling tinggi adalah kemampuan dalam mengidentifikasi, menerapkan, memberikan contoh, menyajikan dan mengembangkan konsep pada operasi tertentu. Kemampuan tersebut dikatakan paling tinggi, karena sebagian besar siswa menjawab dengan benar dan letak kesalahannya sangat sedikit. Sedangkan kemampuan pemahaman konsep matematis yang paling rendah terdapat pada indikator menyatakan ulang konsep yang telah dipelajari, mengklasifikasikan objek-objek 
2694 Kemampuan Pemahaman Konsep Matematis Siswa Sekolah Dasar melalui Pembelajaran Daring dengan Aplikasi Whatsapp - Nurul Fitri Shofiah, Jayanti Putri Purwaningrum, Fina Fakhriyah

DOI: https://doi.org/10.31004/edukatif.v3i5.907

berdasarkan dipenuhi tidaknya persyaratan yang membentuk konsep dan mengaitkan berbagai konsep dalam matematika maupun luar matematika.

\section{UCAPAN TERIMA KASIH}

Ungkapan terimakasih penulis sampaikan kepada pihak Sekolah Dasar Negeri 1 Sidomulyo, Banjarejo, Blora khususnya Ibu Jumiyah Astutiningsih, S.Pd, SD. selaku guru kelas V SDN 1 Sidomulyo, Banjarejo, Blora dan siswa kelas V SDN 1 Sidomulyo yang telah bersedia membantu menyukseskan penelitian serta Bapak Ibu Dosen Universitas Muria Kudus yang telah membimbing dan memberikan bantuan secara teknis selama pelaksanaan riset.

\section{DAFTAR PUSTAKA}

Anggraeni, B. \& P. (2020). Peningkatan Kemampuan Pemahaman Konsep Matematis Siswa Melalui Penggunaan LKPD Berbasis Model Discovery Learning. Jurnal Pendidikan Matematika Universitas Lampung, 8(3), 207-216. Https://Doi.Org/10.23960/Mtk/V8i2.Pp207-216

Arnidha, Y. (2017). Analisis Pemahaman Konsep Matematika Siswa Sekolah Dasar Dalam Penyelesaian Bangun Datar. Jpgmi, 3(1), 53-61.

Arrahim Dan Widayanti. (2018). Sebesar 2,37 Dan T. VI(2), 134-143.

Dewi, W. A. F. (2020). Dampak COVID-19 Terhadap Implementasi Pembelajaran Daring Di Sekolah Dasar. Edukatif: Jurnal Ilmu Pendidikan, 2(1), 55-61. Https://Doi.Org/10.31004/Edukatif.V2i1.89

Handarini Dan Wulandari. (2020). Daring To Draw Causal Claims From Non-Randomized Studies Of Primary Care Interventions. Family Practice, 35(5), 639-643. Https://Doi.Org/10.1093/Fampra/Cmy005

Hutagaol, K. (2013). Pembelajaran Kontekstual Untuk Meningkatkan Kemampuan Representasi Matematis Siswa Sekolah Menengah Pertama. Infinity Journal, 2(1), 85. Https://Doi.Org/10.22460/Infinity.V2i1.27

Jehamun, Philipus. (2020). Mengoptimalkan Pembelajaran Matematika Dengan Metode Daring, [Online], (Https://Bernasnews.Com/Mengoptimalkan-Pembelajaran-Matematika-Dengan-Metode-Daring/ Diakses Pada 9 Februari 2021 Pukul 07.10).

Kartika. (2018). Analisis Kemampuan Pemahaman Konsep Matematis Peserta Didik Kelas Vii SMP Pada Materi Bentuk Aljabar. Jurnal Pendidikan Tambusai, 2(4), 777-785.

Murtianto, Y. H., Muhtarom, M., \& Setiyaningrum, E. D. (2019). Pemahaman Konsep Logaritma Siswa SMA Ditinjau Dari Kemampuan Matematika. Media Penelitian Pendidikan : Jurnal Penelitian Dalam Bidang Pendidikan Dan Pengajaran, 13(1), 36. Https://Doi.Org/10.26877/Mpp.V13i1.5087

Mustakim. (2020). Efektivitas Pembelajaran Daring Menggunakan Media Online Selama Pandemi Covid-19 Pada Mata Pelajaran Matematika. Al Asma: Journal Of Islamic Education, 2(1), 1. Https://Doi.Org/10.24252/Asma.V2i1.13646

Patimah Dan Maula. (2020).Aktivitas Pembelajaran Matematika Pada Materi Pecahan Campuran Berbasis Daring (Melalui Aplikasi Whatsapp) Di Masa Pandemi. JKPD (Jurnal Kajian Pendidikan Dasar), 5. Https://Journal.Unismuh.Ac.Id/Index.Php/Jkpd/Article/View/3679

Pitaloka, S. Dan M. (2013). Keefektifan Model Pembelajaran Matematika Realistik Indonesia Terhadap Kemampuan Pemahaman Konsep Matematika. Unnes Journal Of Mathematics Education., 1(2). Https://Doi.Org/10.15294/Ujme.V1i2.1759

Rahmawati Dan Maula. (2020). Analisis Pemahaman Konsep Matematis Siswa Berdasarkan Teori APOS Melalui Soal Open Ended Berbasis Daring Di Kelas Tinggi Sekolah Dasar. Didaktik: Jurnal Ilmiah PGSD STKIP Subang, 6(1), 155-165. Https://Doi.Org/10.36989/Didaktik.V6i1.122 
2695 Kemampuan Pemahaman Konsep Matematis Siswa Sekolah Dasar melalui Pembelajaran Daring dengan Aplikasi Whatsapp - Nurul Fitri Shofiah, Jayanti Putri Purwaningrum, Fina Fakhriyah

DOI: https://doi.org/10.31004/edukatif.v3i5.907

Sumarno, U. (2010). Berpikir Dan Disposisi Matematik: Apa, Mengapa, Dan Bagaimana Dikembangkan Pada Peserta Didik. Tersedia Di Http://Id.Scribd.Com.Doc/76353753/Berfikir-Dan-Disposisi-MatematikUtari [Diakses 15-04-2021]

Utami, Y. P., \& Cahyono, D. A. D. (2020). Study At Home: Analisis Kesulitan Belajar Matematika Pada Proses Pembelajaran Daring. Jurnal Ilmiah Matematika Realistik, 1(1), 20-26. Https://Doi.Org/10.33365/Ji-Mr.V1i1.252

Yanti, N. Dan I. (2020). Analisis Kemampuan Pemahaman Konsep Matematis Mahasiswa. Logaritma: Jurnal Ilmu-Ilmu Pendidikan Dan Sains, 7(01), 123. Https://Doi.Org/10.24952/Logaritma.V7i01.1669

Yulianah, L., Ni'mah, K., \& Rahayu, D. V. (2020). Analisis Kemampuan Pemahaman Konsep Matematika Siswa Berbantuan Media Schoology. Jurnal Derivat: Jurnal Matematika Dan Pendidikan Matematika, 7(1), 39-45. Https://Doi.Org/10.31316/J.Derivat.V7i1.863 